International Journal of Pharmaceutics \& Pharmacology

Available Online: https://ijpp.edwiserinternational.com

\title{
Letter to Editor: Coronavirus Disease (COVID-19): A Global Health Problem
}

\section{Steward Mudenda*}

Department of Pharmacy, The University of Zambia, School of Health Sciences P.O Box 50110, Lusaka, Zambia

\section{Letter to Editor}

Novel Coronavirus disease 2019 (COVID-19) is a respiratory tract infectious disease that is caused by a Severe Acute Respiratory Syndrome coronavirus 2 (SARS-CoV-2), provisionally called the 2019 novel coronavirus (2019-nCoV) [1]. COVID-19 is a newly identified pathogen and thus termed as a novel coronavirus disease [1]. COVID-19 causes Severe Acute Respiratory Syndrome (SARS) and was declared a global pandemic by the World Health Organization on $11^{\text {th }}$ March 2020 [2]. COVID-19 was first reported on $31^{\text {st }}$ December 2019 in Wuhan, China, and was initially referred to as pneumonia of unknown etiology [3]. The signs and symptoms linked to COVID-19 include fever, dry cough, shortness of breath, sputum production, sore throat, persistent pain or pressure in the chest, myalgia, arthralgia, bluish lips or face, diarrhea, vomiting, respiratory failure, organ failure, septic shock, new confusion or inability to arouse [4]. It may take up to 2 to 14 days for someone to experience signs and symptoms associated with COVID-19 after exposure to the virus $[1,3,5]$. The recommended preventive measures against COVID-19 include adequate hand sanitizing with an alcohol-based hand sanitizer, washing hands regularly for 20 seconds with soap and water, covering your nose and mouth with a face mask or disposable tissue, flexing your elbow when coughing, wearing gloves, social distancing by avoiding close contact with people who are unwell, and staying at home and self-isolate from others if you are unwell [16].

Table 1: Worldometer indicating the top 10 countries with the highest number of COVID-19 cases

\begin{tabular}{|l|l|c|c|c|}
\hline \multicolumn{1}{|c|}{ Country } & \multicolumn{1}{c|}{ Continent } & Confirmed cases & Recovered & Deaths \\
\hline United States of America & North America & 468,895 & 25,928 & 16,697 \\
\hline Spain & Europe & 157,022 & 55,668 & 15,843 \\
\hline Italy & Europe & 143,626 & 28,470 & 18,279 \\
\hline Germany & Europe & 118,235 & 52,407 & 2,607 \\
\hline France & Europe & 117,749 & 23,206 & 12,210 \\
\hline China & Asia & 81,907 & 77,455 & 3,336 \\
\hline Iran & Asia & 66,220 & 32,309 & 4,110 \\
\hline United Kingdom & Europe & 65,077 & 135 & 7,978 \\
\hline Turkey & Asia/Europe & 42,282 & 2,142 & 908 \\
\hline Belgium & Europe & 26,667 & 5.568 & 3,019 \\
\hline
\end{tabular}

Being a respiratory tract infection, just like common colds, most people will be tempted to start selfprescribing of antibiotics. Besides, prescribers will be forced to inappropriately prescribe antibiotics as is evidenced from studies. The increased self and inappropriate prescribing of antibiotics will negatively contribute to another global health problem of antimicrobial resistance [7-9]. Therefore, it must be emphasized that antibiotics must be appropriately prescribed as is recommended in the antimicrobial stewardship programs worldwide. As of today, there is no known treatment for COVID-19. Nevertheless, scientists from across the world are working hard to find a vaccine and therapy for COVID-19. Currently, researchers and pharmaceutical companies are doing 
their best to test some drugs against COVID-19. There must be constant and novel research worldwide to find the treatment for diseases $[10,11]$. Therefore, there is much hope that the vaccine and treatment against COVID-19 will be discovered soon. The COVID-19 is affecting 210 countries and territories around the world and 2 international conveyances. As shown in Table 1, COVID-19 has caused more confirmed cases in Europe than in any other region. There are 1,615,092 confirmed cases, 97,791 deaths, and 362,542 recoveries globally as on $10^{\text {th }}$ March 2020. The United States of America has the highest number of COVID-19 confirmed cases whereas Italy has the highest number of deaths. In Africa, there are 12,987 confirmed cases, 642 deaths, and 1,704 recoveries till date with the first case of COVID-19 reported in Egypt on $14^{\text {th }}$ February 2020. Currently, South Africa has the highest number of COVID-19 confirmed cases in Africa with the first case being reported on the $5^{\text {th }}$ of March 2020. Zambia recorded its first case of COVID-19 on $18^{\text {th }}$ March 2020. These statistics keep on changing every time the Worldometer is updated.

In conclusion, COVID-19 is a global pandemic that requires a multisectoral approach to eradicate. It is a requirement that every individual must abide by the preventive measures recommended by the World Health Organization and Ministries responsible for Health in each country. Together, we shall overcome and conquer the COVID-19 pandemic.

\section{References}

1. World Health Organization, World Health Organization. Report of the WHO-China joint mission on coronavirus disease 2019 (COVID-19).

2. European Centre for Disease Prevention and Control. Novel coronavirus disease 2019 (COVID19) pandemic: increased transmission in the EU/EEA and the UK - sixth update - 12 March 2020. Stockholm: ECDC; 2020.
3. Cascella M, Rajnik M, Cuomo A, et al. Features, Evaluation and Treatment Coronavirus (COVID19). StatPearls. Treasure Island (FL) 2020.

4. Chinese Center for Disease Control and Prevention. Epidemic update and risk assessment of 2019 Novel Coronavirus 2020 [updated 29 January 2020; cited 202029 February]. Available from: http://www.chinacdc.cn/yyrdgz/202001/P0202001 28523354919292.pdf

5. Backer JA, Klinkenberg D, Wallinga J. Incubation period of 2019 novel coronavirus (2019-nCoV) infections among travelers from Wuhan, China, 20 28 January 2020. Eurosurveillance. 2020;25(5).

6. Lynch C, Mahida N, Oppenheim B, et al. Washing our hands of the problems. Journal of Hospital Infection https://doi.org/10.1016/j.jhin.2020.03.010

7. Kalonga J, Hangoma J, Banda M, et al. Antibiotic Prescribing Patterns in Paediatric Patients at Levy Mwanawasa University Teaching Hospital in Lusaka, Zambia. Int J Pharm Pharmacol 2020; 4: 138.

8. Zulu A, Matafwali SK, Banda M, et al. Assessment of knowledge, attitude and practices on antibiotic resistance among undergraduate medical students in the school of medicine at the University of Zambia. Int J Basic Clin Pharmacol 2020; 9: 263270.

9. Mudenda S, Bangara FF, Sitali J, et al. Knowledge, Attitude, and Practices on Antibiotic Resistance among Pharmacists at the University Teaching Hospitals in Lusaka, Zambia. J Harmonized Res 2019; 8: 12-24.

10. Jahangir MA, Rao AP. Letter to Editor: Recent Advancement in Blood Cancer Research and Management. Int J Pharm Pharmacol 2019; 3: 135.

11. Jahangir MA, Muheem A, Rizvi MF, et al. Coronavirus (COVID-19): History, Current Knowledge and Pipeline Medications. Int J Pharm Pharmacol 2020; 4: 140.
*Corresponding author: Mr. Steward Mudenda, Department of Pharmacy, The University of Zambia, School of Health Sciences P.O Box 50110, Lusaka, Zambia; E-mail: steward.mudenda@unza.zm
Article Info

Received 09 April 2020

Revised 10 April 2020

Published 10 April 2020

Copyright: (C2020 Mudenda S. This article is distributed under the terms of the Creative Commons Attribution 4.0 International License (http://creativecommons.org/licenses/by/4.0/), which permits unrestricted use, distribution, and reproduction in any medium, provided you give appropriate credit to the original author(s) and the source, provide a link to the Creative Commons license, and indicate if changes were made. 